IRSH 47 (2002), pp. 423-452 DOI: I0.1017/S002085900200072X

(C) 2002 Internationaal Instituut voor Sociale Geschiedenis

\title{
Anthropology, Family History, and the Concept of Strategy
}

\author{
Pier Paolo Viazzo and Katherine A. Lynch
}

\section{INTRODUCTION}

In this essay, we consider family history as a common field of substantive and theoretical interest shaped by contacts among several disciplines. These disciplines obviously include social history and population studies, but also - and rather prominently - social anthropology. One major component of the growth of family history has been the increasing amount of attention that historians pay to topics such as marriage, kinship, and the family, which have long been of central significance in the anthropological investigation of social structure. On the other hand, anthropologists have become aware of the serious limitations of synchronic, present-oriented field research, and most of them now probably agree that historical analysis is essential if they are to understand social and cultural processes. This realization has gradually changed many anthropologists from reluctant consumers of historical work into active and often quite enthusiastic producers. ${ }^{\mathrm{I}}$

The fruitfulness of this rapprochement was perhaps best demonstrated as early as the I970s by the advances made possible by the adoption in family history of the anthropological concept of developmental cycle of the domestic group. Although Chayanov's work already foreshadowed this concept, it was independently formulated in 1949 by Meyer Fortes, one of the leading British social anthropologists, and further refined by Fortes himself and by his colleagues and pupils in Cambridge in the I950s. ${ }^{2}$ When its potentialities were revealed to the nascent field of family history by the works of anthropologists like Goody and Hammel and,

I. See John Davis, "Social Anthropology and the Consumption of History", Theory and Society, 9 (1980), pp. 519-537. See also David I. Kertzer, "Anthropology and Family History", Journal of Family History, 9 (1984), pp. 20I-2 16; Susan Kellogg, "Histories for Anthropology: Ten Years of Historical Research and Writing by Anthropologists, I980-1990", Social Science History, is (I99I), pp. 417-455; and Pier Paolo Viazzo, Introduzione all'antropologia storica (Rome, 2000), pp. I $32-164$.

2. See Meyer Fortes, "Time and Social Structure: An Ashanti Case Study", in idem (ed.), Social Structure: Studies Presented to A.R. Radcliffe-Brown (Oxford, 1949), now in idem, Time and Social Structure and Other Essays (London, 1970), pp. I-32, and idem, "Introduction" to Jack Goody (ed.), The Developmental Cycle in Domestic Groups (Cambridge, I958), pp. I-I4. 
very effectively, by Lutz Berkner's influential study of stem-family organization in a part of Austria, this concept was indeed welcomed in many quarters as a sort of panacea. ${ }^{3}$ We now know, however, that it was no panacea. As subsequent research showed, in some cases the descriptive and predictive value of models based on the concept of developmental cycle was very limited, as was the models' inability to distinguish between the current situation of successive cohorts and the consequences of secular changes. ${ }^{4}$ Nevertheless, on balance, the effects of the adoption of a "developmental approach" concept were beneficial, marking the whole discipline.

It would seem at first glance that we can say the same about the concept of "strategy". Like the notion of developmental cycle, it has been borrowed largely from anthropology, being regarded by many family historians as a powerful tool to go beyond a static and formalistic approach.5 In the last few years, the notion of strategy has been widely used in the literature, where it is increasingly frequent to speak not only of family strategies but also of marriage strategies, inheritance strategies, fertility strategies, migration strategies, and so forth - the latter being conceptualized as aspects or components of more general family strategies corresponding to the various stages of the developmental cycle. ${ }^{6}$

There is, however, an important difference. Whatever its limitations, the concept of developmental cycle was formulated in a clear way from the beginning and was used fairly consistently. Despite repeated attempts to establish it as the core of a new research paradigm, however, the notion of

3. See Jack Goody's and Eugene Hammel's contributions to Peter Laslett and Richard Wall (eds), Household and Family in Past Time (Cambridge, I972); and Lutz K. Berkner, "The Stem Family and the Developmental Cycle of the Peasant Household", American Historical Review, 77 (1972), pp. 398-418.

4. For example, see Peter Czap, "A Large Family, the Peasant's Greatest Wealth: Serf Households in Mishino, Russia, I814-1858”, in Richard Wall, Jean Robin, and Peter Laslett (eds), Family Forms in Historic Europe (Cambridge, I983), pp. I05-I I I, esp. I 35-I4I.

5. Patrice Bourdelais and Vincent Gourdon, "L'histoire de la famille dans les revues françaises (1960-1995): la prégnance de l'anthropologie”, Annales de Démographie Historique, 37, 2 (2000), pp. 5-48, 30 .

6. For an overview and critical discussion of the literature, see Lucia Ferrante, "Struttura o strategia? Discussione sulla storia della famiglia”, Quaderni Storici, I9 (1984), pp. 6 I 2-626. Also see the contributions by Leslie Page Moch, Nancy Folbre, Daniel Scott Smith, Laurel L. Cornell, and Louise A. Tilly to an SSHA meeting on "Family Strategy", published in Historical Methods, 20 (1987), pp. I I3-I 25; Pat Straw and Stephen Kendrick, "The Subtlety of Strategies: Towards an Understanding of the Meaning of Family Life Stories”, Life Stories/Récits de Vie, 4 (1988), pp. 36-48; Phyllis Moen and Elaine Wethington, "The Concept of Family Adaptive Stategies", Annual Review of Sociology, I8 (1992), pp. 233-25I; Michel Baud and Theo Engelen, "Introduction: Structure or Strategy? Essays on Family Demography, and Labor from the Dutch N.W. Posthumus Institute", The History of the Family, 2 (1997), pp. 347-354; and Laurence Fontaine and Jürgen Schlumbohm, "Household Strategies for Survival: An Introduction", in Laurence Fontaine and Jürgen Schlumbohm (eds), Housebold Strategies for Survival, I600-2000 (Cambridge, 2000), pp. I-I 7 . 
strategy appears to be ambiguous and ill-defined. We can legitimately wonder whether we are dealing here with a well-developed concept or just with a fashionable and rather equivocal term. A certain amount of polysemy can of course be expected when a term is used - as is the case with "strategy" - across the social sciences, from economics to sociobiology. However, even if we restrict our attention to family history and to social anthropology, we immediately notice an alarming degree of looseness and confusion.

Our impression is that we are not yet in a position simply to add more empirical cases in order to "articulate" this paradigm. Nor can we expect that a simple accumulation of empirical cases vaguely headed under the label "strategy" will eventually clarify the concept. What is necessary is a reassessment of both the potentialities and the limitations of this notion. As early as 1987, Leslie Page Moch remarked: "it is especially useful to do so now before reification sets in and family strategies are either seen as the appropriate concept for all behaviors and situations or grasped at to explain phenomena that seem otherwise inexplicable". In this context, it is important to reflect on the anthropological roots of the notion of family strategy and how anthropologists and historians have used it - all the more so when we consider that family historians can hardly avoid facing a major problem that has long bewildered social and cultural anthropologists, namely whether family strategies "may be merely a figment of the historian's imagination rather than a key to behavior". 7 In view of the current tendency to apply (sometimes indiscriminately) the notion of family strategy to all historical periods, an effort to clarify the issue concerning the relationships between varying degrees of control and the possibility for conscious strategy appears to be an important task for both history and anthropology.

\section{ANTHROPOLOGICAL BEGINNINGS: BARTH AND BOURDIEU}

Fredrik Barth introduced the concept of strategy into social anthropology as part of his effort to replace the structuralist approach based on the theory of unilineal descent groups with that brand of methodological individualism that has come to be known as "transactionalism". 8 The

7. Leslie Page Moch, "Historians and Family Strategies", Historical Methods, 20 (1987), pp. II3-IIS, II 4 .

8. For a revealing and authoritative outline of the structuralist approach in British social anthropology and of the unilineal descent group theory, see Meyer Fortes, Kinship and the Social Order (Chicago, IL, I969). See also Louis Dumont, Introduction à deux théories d'anthropologie sociale (Paris, I97I). On "transactionalism" as a reaction to the crisis of unilineal descent group theory, see Jeremy Boissevain, Friends of Friends: Networks, Manipulators and Coalitions (Oxford, I974), pp. I-23. 
Fortesian notion of developmental cycle had itself been an attempt to amend the structuralist approach by making it more dynamic. However, Barth's attack, first launched in his brilliant study of the political system of the Swat Pathans of Pakistan, was more radical. ${ }^{9}$ Following the lead of Raymond Firth, Barth argued that, particularly in the study of social change, it was essential to shift the focus of enquiry from the analysis of the set of jural relations obtaining between various kinship groups - classically the unilineal descent groups ("lineages") of sub-Saharan Africa - to the study of planned actions, decisions and individual choices. ${ }^{1 \circ}$

Although he conceded that structural factors defined and restricted the alternatives that each actor faced, he nonetheless maintained that it was preferable to analyze social organization rather than social structure social organization being the cumulative result of a multitude of individual choices. To be sure, in both his I 959 book on the Swat Pathans and in his Models of Social Organization, which was published seven years later, the keyword was not "strategy". The emphasis was rather on "exchange" or, even more, on "transaction", which Barth defined as "a sequence of interaction systematically governed by reciprocity". ${ }^{\text {I }}$ Nevertheless, what he had in mind was a strategic or game-theoretic mode of interaction. ${ }^{\mathrm{I}} \mathrm{He}$ actually stated quite forcefully and explicitly that transactions should be analyzed "by means of a strategic model, as a game of strategy". ${ }^{13}$

Barth's model shared the primacy he granted to calculative behavior, the search for a generative approach, and the substantial debt to exchange theory with a number of other models that sociologists and anthropologists put forward in those years. There were, in particular, obvious similarities with the strategic approach that Pierre Bourdieu advocated in two works published in 1972, his Outline of a Theory of Practice, where he relied mainly on his ethnography of the Kabyles of Algeria, and the celebrated article on marriage strategies and the stem family in the Pyrenean region of Béarn, which appeared in the special issue of the Annales ESC devoted to family history. ${ }^{14}$ There were also several significant differences.

\footnotetext{
9. Fredrik Barth, Political Leadership among Swat Pathans (London, 1959).

I0. See especially Raymond Firth, Elements of Social Organization (London, 1951); Barth acknowledges his debt to Firth in Political Leadership, p. 3.

I I. Fredrik Barth, Models of Social Organization (London, I966), p. 4.

I 2. For a useful discussion of the strategic or game-theoretic mode of interaction, see Jon Elster, Ulysses and the Sirens: Studies in Rationality and Irrationality (Cambridge, I979), pp. I 8-28.

I3. Barth, Models of Social Organization, p. 4. See also idem, "Segmentary Opposition and the Theory of Games: A Study of Pathan Organization", Journal of the Royal Anthropological Institute, 89 (1959), pp. 5-21.

I4. Pierre Bourdieu, Esquisse d'une théorie de la pratique. Trois études d'ethnologie kabyle (Geneva, 1972), a revised version of which was published in English as Outline of a Theory of Practice (Cambridge, I977); and idem, "Les stratégies matrimoniales dans le système de reproduction”, Annales ESC, 27 (I972), pp. I I05-I I 27.
} 
The first difference was that Barth's model focused on strategies that individual actors pursued, social institutions being regarded as founded and maintained by individuals to fulfill their ends, consciously framed independently of the institutions. ${ }^{\mathrm{IS}}$ Bourdieu's work, on the other hand, focused on strategies that collective actors such as families or kin groups pursued. This is particularly the impression one receives from the paper in the Annales ESC, where Bourdieu discussed at length the devices that Béarn peasants used to keep the family property undivided. There was little trace in this paper of the aggressive entrepreneurs and ambitious village politicians who were the protagonists of Barth's analyses and those of other transactionalist anthropologists.

Barth's and Bourdieu's analytical frameworks were also significantly different, for Bourdieu did not seem to regard family strategies as the outcome of rational decision-making. At one point, he even stated that strategies might be more subconscious than conscious. ${ }^{16}$ By this, however, he meant that strategies are rooted in - or, as he says, "generated by" - a small number of implicit principles, a "system of predispositions inculcated by the material circumstances of life and by family upbringing". ${ }^{17}$ Strategies, in his view, often varied according to circumstances, and depended on changing sets of constraints. He believed that they could typically be relatively short-term affairs; and it is indisputable (in spite of some characteristic ambiguities in Bourdieu's text) that they are, if not rational, certainly intentional. ${ }^{18}$ In the Béarn, the implicit principles included not only the categorical imperative that the estate be kept undivided, but also other unquestioned, "self-evident" principles such as the primacy of men over women, and the primacy of the eldest over younger siblings. He implied that because of family upbringing, elders expected younger brothers to accept that the eldest brother would inherit the land, and be prepared to remain celibate in order not to threaten the integrity of the estate. Bourdieu seemed to think that what was good for the family was also good for all its members.

A final and important difference between Barth and Bourdieu was that they were reacting against quite separate, and indeed mutually hostile,

I 5. This version of the social contract theory is central to several varieties of methodological individualism. See, for example, Steven Lukes, "Methodological Individualism Reconsidered", British Journal of Sociology, I9 (I968), pp. I 19-I 29.

I6. Bourdieu, "Stratégies matrimoniales", p. I I07.

17. Ibid., p. I I06: "le système des dispositions inculquées par les conditions d'existence et par l'éducation familiale"; and p. I I I 4: "tout se passe comme si toutes les stratégies s'engendraient à partir d'un petit nombre de principes implicites". The anthropological literature of the early I970s considered it of the utmost importance to distinguish the notion of "implicit" as quite different from "unconscious". See Dan Sperber, Le symbolisme en général (Paris, 1974); and Mary Douglas, Implicit Meanings (London, 1975).

I8. On intentionality as crucial to the definition of strategy, see Elster, Ulysses and the Sirens, pp. I-34. 
varieties of anthropological structuralism. Whereas Barth's target was the British brand of structuralism usually associated with the names of Radcliffe-Brown, Evans-Pritchard, and Fortes, Bourdieu directed his scathing attack mainly against Lévi-Strauss and his French followers. ${ }^{19}$ It is easy to miss this point if one reads only the article published in the Annales ESC, where Bourdieu mainly stressed the limitations of a legalistic approach in the study of inheritance practices in peasant societies. If one turns to his Outline of a Theory of Practice, however, it is clear that he considered a strategic approach to be a badly needed antidote to the then triumphant structuralist theory that Claude Lévi-Strauss pioneered. Bourdieu was particularly critical of the structuralists' readiness to reduce the study of marriage to the analysis of rules allegedly governing kinship and alliance relations. Relying on his ethnographic data on the Kabyles, Bourdieu provided an impressive array of examples showing that marriages that were genealogically equivalent - and that a structuralist anthropologist would immediately interpret as obeying a structural rule may in fact "have [had] different, even opposite, meaning and functions, depending on the strategies in which they [we]re involved". ${ }^{\circ}$ For Bourdieu, rule and structure on the one hand, and practice and strategy on the other, were antithetical and irreconcilable concepts.

Given the diffusion of his work, it is important to emphasize that Bourdieu actually focused on "matrimonial" and not "family" strategies, properly speaking. He was mainly interested in understanding whether and how strategies affected the marriages of all the children of one lineage. Furthermore, his notion of matrimonial strategies took shape when he was at work on societies that furnished direct evidence (either oral or written) that the matrimonial choices of the younger generation bore the imprint of a strategy that the older generation imposed. It was thus clear from Bourdieu's evidence that "matrimonial strategies" actually existed both in the Kabyle society of North Africa, where matrimonial strategies appeared rather more aggressive, and the peasant society of the Béarn, where they seem to have taken on a more defensive aspect. ${ }^{21}$

What exactly did Bourdieu mean by matrimonial strategies in these two societies? Evidence he collected seemed to suggest that in both societies, an

19. On the difference between the French and the British brands of anthropological structuralism, see Dumont, Introduction à deux théories.

20. Bourdieu, Outline of a Theory of Practice, p. 48.

2 I. Pierre Bourdieu, In Other Words: Essays towards a Reflexive Sociology (Stanford, CA, 1990), p. 59. The author notes how "familiar" the matrimonial practices of families in the Béarn were to him, given his research on the Kabyle people. He also observes (p. 69) that memoirs of the court of Louis XIV or Proust's novels offer more insight into matrimonial strategies than theoretical anthropological texts. His work focuses on the "negotiators", and the strategic "diplomacy" involved in arranging marriages, whether among members of the nobility or Béarnais peasants. On parental "marriage strategy" in another peasant setting, see David Warren Sabean, Property, Production, and Family in Neckarbausen, I700-I870 (Cambridge, 1990), pp. 329-334. 
older generation, or the family heads, thought and acted in ways that most people, using a common-sense definition of strategy, would recognize as strategic in nature. They sought to time the marriages of their children to partners who had various desirable characteristics. In the case of the Béarn region, family heads (and perhaps other members as well) sought to reproduce a family situation in which an heir (or heiress) and spouse would reside in the family "house", while fulfilling their responsibility to distribute family assets to sibling non-heirs in an equitable fashion and providing for unmarried non-heirs, should they choose to remain as residents. The matrimonial strategies in these two societies seem to have involved a widespread awareness of the ultimate goals of retaining or expanding the wealth of the lineage or house as well as certain familiar tactics that elders routinely used in the local marriage market to advance their strategies.

The sorts of strategies that Bourdieu found in North Africa and Pyrenean France were, of course, quite familiar to social historians studying the families of the European nobility or royalty, who found ample direct evidence that elders - parents or fathers of families - engaged in strategic thinking when they chose different careers for their sons and daughters. These strategists apparently tried to balance the group's available financial resources and the number of siblings against considerations of individual children's birth order, their aptitudes, and desirability. Thus, parents (or fathers) tried to fit individual fates into some larger plan or strategy for their nuclear family or larger lineage. ${ }^{22}$

Thus, despite Bourdieu's statements about the subconscious aspect of strategies, his empirical work suggested that the matrimonial strategies he witnessed were quite conscious, manifesting themselves in multiple tactical decisions through time about the marriages of successive offspring. As a previous commentator on the "family strategies" question noted, all strategies require specific tactics - in this case choices tailored to each individual child, while controlling for the needs of the group as the strategy maker conceives them. ${ }^{23}$ This suggests some important methodological implications. We may be able to observe strategies only through time, by adopting a longitudinal perspective. Social historians or anthropologists may need to keep all members of families or lineages under

22. For a recent addition to this long line of research, see Joanne Baker, "Female Monasticism and Family Strategy: The Guises and Saint Pierre de Reims", Sixteenth-Century Journal, 28 (1997), pp. I09I-I I08.

23. Bourdieu, In Other Words, p. 68, notes this manifestation of a "matrimonial strategy" in the choice of partners for multiple children. In "Stratégies matrimoniales" (p. I I 20), he argues the necessity of seeing each marriage as a "moment in a series of material and symbolic exchanges, the economic and symbolic capital that a family can engage in the marriage of one of its children being dependent in large part on the position that this exchange occupies in the matrimonial bistory of the family" (our emphasis). Laurel Cornell usefully distinguishes strategies and tactics in "Where can Family Strategies Exist?", Historical Methods, 20 (1987), pp. I20-I23, I 20. 
observation for at least a generation or so to observe those multiple decisions that spring from strategies in action. Furthermore, like Bourdieu, they must be careful to consider matrimonial or other strategies within the context of the habitus of the people whom they are studying - what Bourdieu defined as the "strategy-generating principle enabling agents to cope with unforeseen and ever-changing situations". ${ }^{24}$

\section{FAMILY STRATEGIES IN SOCIAL HISTORY}

Originally published in 1972, Bourdieu's paper on the Béarn appeared in English in 1976 in the selection of articles on the family from the Annales ESC edited by Robert Forster and Orest Ranum. ${ }^{25}$ This largely explains its impact on family historians well beyond the boundaries of France. In the I970s, the concept of strategy was, however, already emerging quite independently in family history. An important example was the article Natalie Zemon Davis published in the special issue of Daedalus on the family, where she explicitly proposed to characterize the early modern family life in terms of strategy. ${ }^{26}$ Family strategies, she noted, may vary. Some families

[...] want merely to pass on the family's patrimony as intact as possible to those of the next generation who will stand for the house and its name in the father's line. Others want to enhance that patrimony; still others want to create a patrimony if it does not already exist.

However, in all cases the historian can detect some planning - possibly a long-term planning - "for a family future during and beyond the lifetimes of the current parents". ${ }^{27}$

Although Davis's remarks displayed obvious similarities with most other discussions of the concept of family strategy, she made a number of critical points. The first was her emphasis on the fact that it is not "natural" or inevitable for families to pursue these strategies, universal as they may appear to be at first sight. ${ }^{28}$ Family strategies, Davis argued, became possible or conceivable in western Europe only at a given stage of historical evolution, namely in the sixteenth and seventeenth centuries, when, in her judgment, the interests in the immediate family became more

24. Pierre Bourdieu, "Structures and the Habitus", in Outline of a Theory of Practice, p. 72. We are grateful to Rick Maddox for his comments on this point.

25. Pierre Bourdieu, "Marriage Strategies as Strategies of Social Reproduction", in Robert Forster and Orest Ranum (eds), Family and Society: Selections from the "Annales" (Baltimore, MD, 1976), pp. I17-I44.

26. Natalie Zemon Davis, "Ghosts, Kin, and Progeny: Some Features of Family Life in Early Modern France”, Daedalus, 106 (1977), pp. 87-I I4.

27. Ibid., p. 87 .

28. Ibid., p. 88 . 
sharply demarcated from those of the wider kinship group. ${ }^{29}$ For Davis there was, therefore, no point in talking of family strategies in the Middle Ages. Moreover, since she maintained that only families above the level of the very poor could pursue strategies, there was little room in her argument for the concept of "survival strategy". $3^{\circ}$ Thus, her notion of strategy seemed to be rather restrictive. Davis was inclined to consider strategy less as an analytical concept than an historical attribute of families after the sixteenth century - a symptom of a changed habit of mind, of a new notion of family and kinship.

Despite her emphasis on family strategies, Davis's paper was not a theoretical or methodological manifesto advocating a strategic approach to family history. To find such a manifesto one has to return to Louise Tilly's I979 article on "Individual Lives and Family Strategies in the French Proletariat". ${ }^{31}$ As the very title of the paper suggested, Tilly's notion of family strategy was more wide-ranging than Davis's. More importantly, Tilly saw strategy as a concept of unique analytical value for examining "the links between individual lives and collective behavior" and reintroducing "intentionality and uncertainty in history, without abandoning systematic analysis". Following Bourdieu, she defined the concept of family strategy as "a series of hypotheses about 'implicit principles' [...] less rigid or articulated than decision rules, by which the household, not the individual or the society as a whole, acts as the unit of decision making". ${ }^{2}$ Tilly's use of strategy obviously owed a great deal to Bourdieu. However, in employing the adjective "family", Tilly broadened and democratized the term considerably, changing her focus from matrimony's role in the perpetuation of lineages to the survival of poor, working-class families during the processes of industrialization and proletarianization. ${ }^{33}$ Moreover, her transformation of the term from one designed to model a rather narrow range of questions of control over matrimonial choices or the transmission of property across generations into the more general notion of "family strategies", while appealing to many, also exacerbated some of the ambiguities of the concept as Bourdieu had articulated it.

29. Ibid., pp. 100-105.

30. Ibid., pp. 87, 92. On "survival strategies", see Fontaine and Schlumbohm, "Household Strategies", pp. 9-10.

31. Louise A. Tilly, "Individual Lives and Family Strategies in the French Proletariat", Journal of Family History, 4 (1979), pp. I37-I 52.

32. Ibid., p. I38.

33. See also Louise A. Tilly and Joan W. Scott, Women, Work, and Family (New York, I987), p. 7. Here, the authors state that what they mean by strategy goes beyond conscious calculation. It has "a broader implication, one that enables us to think about how people make decisions in the face of changing economic circumstances. Particularly in the periods we examined, when rational calculation was practiced at all levels of social life, an assessment of behavior in terms of strategies does not seem misplaced." 
In Bourdieu's work on matrimonial strategies, whatever its ambiguities in other respects, it was clear that elders were the subjects and the matrimonial choices of a younger generation the objects of these strategies. Bourdieu was never ambiguous about who were the main strategists. In Tilly's use of family strategy, however, it was often unclear whether "the family" as a collective group was object, subject, or both object and subject of the strategy. Tilly stated: "families are conceived of as acting in a unitary way to make decisions", but admitted that there was actually no way to assess whether that was accurate. ${ }^{34}$ As noted earlier, Bourdieu's own work suggested that he thought very little about the question of families' decision-making process, apparently accepting the kind of convenient fiction of group interest that Tilly later expressed in her work. ${ }^{35}$

In one of her theoretical statements, Tilly tried to address the problem explicitly by suggesting that historians use family strategies in two ways one which assumes that strategies actually existed in the minds and actions of the historical actors, and the other in which strategies exist only in the minds of the analysts. ${ }^{36}$ In her empirical work using the concept, she seems to have believed that family members were consciously pursuing shared strategies, and that individuals who composed those families accepted them. There was, however, little direct evidence from working-class families (in contrast to the letters or diaries of the European nobility) to document the existence of such strategies. Thus, her work seems mainly to have inferred strategies from behavior. While advocating two quite different approaches to using family strategy in her more theoretical pronouncements on the subject, Tilly's empirical work was somewhat unclear about whether the family strategies she studied actually existed in the minds of those she studied and directed their behavior, or were mainly models she invented after the fact to help explain certain behavior patterns she had noted.

The problem of determining whether people were conscious of the strategies they were performing is, in many ways, a variant of anthropologists' problem of "getting into the natives' heads", which has been at the core of the program of cognitive anthropology since the ig6os. In

34. Tilly, "Individual Lives", p. I39. In the conclusion (p. I 50), she noted that the "costs" of various strategies, such as the high fertility strategy (discussed below), weighed more heavily on women and children.

35. Bourdieu, In Other Words, pp. 69-70. Bourdieu roundly denies this is a problem with the term "matrimonial strategy", but fails to address the point in any substantive way. He admitted the existence of conflicts within the family in his earlier work, but saw these cases of internal conflict as "pathological" and "exceptional" ("Stratégies matrimoniales", p. i I I7); the younger children, who were "structural victims" accepted their fates relatively peacefully (p. I I 23).

36. Louise A. Tilly, "Beyond Family Strategies, What?", Historical Methods, 20 (1987), pp. I23I 25 , I 24. 
anthropology, a broad division exists between those who think that they should give primacy to actors' points of view, and those who maintain that the task of anthropology is to go beyond the perception and explanation of the actors to bring to light regularities, tendencies, and structural connections of which the natives may not be fully aware. Supporters of the two positions have now been engaged for nearly thirty years in a long and at times acrimonious debate (generally known in anthropological jargon as the "emic" vs "etic" controversy). ${ }^{37}$ The impression we get is that in anthropology the preference a scholar accords to either approach results essentially from an epistemological choice. In history, on the other hand, there are reasons to suspect that the adoption of an "analytical" standpoint is more often a matter of expediency. This is not always the case, of course. Economic historian Valerie Oppenheimer, for instance, voiced her conviction that a profitable study of family strategies should rest on the observer's evaluation of the effectiveness of behavior patterns, without implying that the individuals involved perceived these as strategies. ${ }^{38}$ In other cases, historians are aware that a pattern of behavioral outcomes may or may not reflect conscious planning. However, they prefer to ignore the difficulty (and infer the existence of strategic behavior and aims from these outcomes) simply because they are unable to speak to the people involved and therefore have no alternative. ${ }^{39}$

These themes of consciousness and consensus around family strategies were also vitally important in Tamara Hareven's work on the history of the family in North America. Here, the author went well beyond the limits of marriage choices or household survival - both based upon the dominance of an elder generation - to assess the strategic behavior of kin members of all ages and relations to one another. In contrast to Tilly, who believed that adult children often loosened themselves from the terms of family strategies once they left the parental household, Hareven saw

37. Marvin Harris, The Rise of Anthropological Theory (New York, I968), started the controversy. It provides a thorough discussion of the terms "emic" and "etic", and still represents an important reference point in the debate.

38. Valerie Kinkade Oppenheimer, "The Changing Nature of Life-Cycle Squeezes", in Robert W. Fogel et al. (eds), Aging: Stability and Change in the Family (New York, I98I), pp. 47-8I, especially 54-55. It is perhaps worth noting that Oppenheimer, like the proponents of the "etic" approach in anthropology, uses the concept of strategy "in the way that biologists do when they discuss biologically adaptive behaviors in an evolutionary sense of the term" (p. 55 ).

39. See Daniel Scott Smith, "Family Strategy: More than a Metaphor?", Historical Methods, 20 (1987), pp. I I 8- I I 9, I I 8; Straw and Kendrick, "The Subtlety of Strategies", pp. 39-40; and, most recently, Fontaine and Schlumbohm, "Household Strategies", p. 8, who remark that "more often than not, [historians] have to infer actors' strategies from documents mirroring only the results of behaviour, whereas anthropologists not only observe but also question the persons they study". 
individuals' lives fitting into these strategies well beyond this point..$^{\circ}$ It was no longer a case of working-class parents enforcing tactics they had adopted on the next generation, but of a band of relatives conforming to multigenerational rules of conduct in the pursuit of extended family solidarity. Hareven argued that adult workers made a number of decisions about outmigration from their birthplaces, employment, and survival in new surroundings, taking into consideration the good of the larger kin group.

In Hareven's work, family as well as individual strategies shaped people's paths of migration. In the move from Quebec to Manchester, New Hampshire, uncles and aunts took nieces and nephews into their home. In some cases, individuals were willing to sacrifice their own interests for other family members, delaying or rejecting marriage for themselves in order to care for younger siblings or aged parents. They did this in the name of family. Hareven wrote:

The sense of duty to family was a manifestation of family culture - a set of values that entailed not only a commitment to the well-being and self-reliance or survival of the family but one that took priority over individual needs and personal happiness. The preservation of family autonomy was valued as a more important goal than individual fulfillment. ${ }^{4 \mathrm{I}}$

\section{Moreover,}

[...] [b]oth career choices and economic decisions were made within the family matrix. Families might be described as being composed of units that were switched around as the need arose. Each unit was relied upon and used when appropriate. Following such strategies, families timed the movement of members in response to both individual schedules and external conditions. Family strategies revolved around a variety of decisions: when to migrate, when to return, when those who were left behind should rejoin the family in Manchester, who should be encouraged to explore other working opportunities, who should be encouraged to marry, and who should be pressured to stay at home. $4^{2}$

The passive voice in the passage cited above, and the sense of the family as a collective actor, suggest some of the theoretical difficulties with using family strategy. At best, Hareven used family strategy in this text as a shorthand way of summarizing a number of decisions, thereby foregoing a microanalysis of decisions one by one. Using the notion of family strategy was simply more convenient than answering questions about each act of

40. Tilly, "Beyond Family Strategies", pp. I 49- I 50, suggests that adult women living apart from their families may have done so in "consequence of independence of family strategy, defiance of family strategy, or acceptance of family decisions which sent them out of the household". No direct evidence enabled her to distinguish among these possibilities, however.

4I. Tamara K. Hareven, Family Time and Industrial Time: The Relationship Between the Family and Work in a New England Industrial Community (Cambridge, 1982), p. I08.

42. Ibid., pp. 109-1 10. 
migration and determining who the decision-makers were. Unfortunately, however, the use of the collective noun can begin to blur or even remove the sense of human agency that the notion of strategy was originally intended to reveal. Here, it is not individuals, but rather disembodied strategies that risk taking center stage.

Of course, the main point that Tilly and Hareven and other social historians wanted to make was that to understand the behavior of individuals adequately, we need to know how individuals were constrained by considerations external to themselves - including perceptions about the wellbeing of their kin. Furthermore, Hareven wanted to show that people conformed to some more complex, extended-family strategies not merely out of instrumental calculation - as Michael Anderson suggested in his work on Preston - but out of a sense of loyalty, affection, or concern. ${ }^{43}$

Interestingly, Hareven's work did expose the conflicts that often broke out between the desires of individuals and the dictates of larger family strategies. Much more than Bourdieu, historians like Tilly and Hareven gave insight into the limitations of the holds of household, family, or kinship strategies on individual behavior. As suggested earlier, Tilly hypothesized that when adult children moved out of the parental household, their migration inherently diminished the hold of group strategies upon their behavior. Even Hareven gave numerous examples of individuals who reached a point where they had had quite enough of thinking about their kin's needs, and were determined to focus upon themselves. ${ }^{44}$ Despite the reifying tendency of the notion of family strategies, therefore, these social historians, using a variety of source material, did allow the voices of individuals to be heard, and the tensions surrounding imputed strategies to be exposed for the reader. It is true, however, that neither Tilly nor Hareven was interested, or in some instances able to identify, exactly who was responsible for the multiple

43. "In the past, the family made decisions as a collective, corporate unit, rather than as the sum of its individual members"; Tamara K. Hareven, "A Complex Relationship: Family Strategies and the Processes of Economic and Social Change", in Roger Friedland and A.F. Robertson (eds), Beyond the Marketplace: Rethinking Economy and Society (New York, I990), pp. 21 5244, 2 17. Cf. Michael Anderson, Family Structure in Nineteenth-Century Lancashire (Cambridge, I971).

44. Hareven, Family Time, pp. I09-I I 2. In her study of working-class autobiographies, Mary Jo Maynes notes the bitterness that adult children often expressed over the harshness of their working lives as children within such households. Though the adult children well understood that their parents were themselves victimized by the inequalities of the social system, the children's perceptions (and their perceptions even as adults) included real resentment. These stories reveal that parents and not "families" or "households" formed and enforced choices about work for the younger generation. See Mary Jo Maynes, Taking the Hard Road: Life Course in French and German Workers' Autobiographies in the Era of Industrialization (Chapel Hill, NC, I995), pp. 78-8I. 
decisions about such things as work and migration that different individuals made through time. ${ }^{45}$

\section{STRATEGIES OR STRUCTURES? LÉVI-STRAUSS'S LEGACY}

Tilly's formulation appeared to bridge the gap between the anthropological tradition represented by Bourdieu and this new line of research in social and economic history, and could have been expected to provide a common focus for the various major streams in historical and anthropological studies of the family. This, however, did not happen. In particular, while using the term strategy rather heavily, some of the most sophisticated anthropological works on kinship and marriage bore LéviStrauss's influence, and moved in a direction which was the opposite of what Bourdieu might have envisaged. Of special relevance in this respect, were the studies of Pierre Lamaison on the French region of Gévaudan, which used historical evidence to explore some thorny questions raised by Lévi-Strauss in his famous book on the elementary structures of kinship, and the theories advanced by Lévi-Strauss's successor in Paris, Françoise Héritier. ${ }^{46}$

As is well known, Lévi-Strauss only dealt with kinship systems characterized by "positive" rules prescribing marriage with certain categories of kin - systems which he termed the "elementary structures of kinship". He left to future generations of anthropologists the study of so-called "complex" structures, i.e. systems where marriage is only constrained by "negative" rules probibiting marriage with certain categories of kin. Western Europe, past and present, offers familiar examples of "complex" systems in which marriage is prohibited within a number of degrees of consanguinity and affinity. Lévi-Strauss predicted that where positive rules did not exist, the range of possible alternatives would be so wide that marriage could be studied only by means of statistical models that took into account demography, class, occupation, and spatial and social mobility. Both Lamaison and Héritier tried to demonstrate that even in "complex" systems, the role of kinship was greater than Lévi-Strauss expected and that regularities in marriage exchange could be detected and represented by models that closely

45. Already in the new 1987 edition of Women, Work, and Family, Tilly and Scott were addressing this kind of criticism of the "family strategy" concept. See p. 9 for a long statement on the need for better analysis of intrafamily decision-making in the study of "family strategies". We thank Baruch Fischoff for his comments about the importance of this dimension of strategic thinking.

46. Claude Lévi-Strauss, Les structures élémentaires de la parenté (Paris, I949). See also his important paper "The Future of Kinship Studies", Proceedings of the Royal Anthropological Institute, (1965), pp. I3-22. 
resembled those Lévi-Strauss himself had used in the analysis of elementary structures.

At first glance, the picture that Lamaison presented in a very interesting and original article published in I979, "Les stratégies matrimoniales dans un système complexe de parenté", was in many ways reminiscent of Bourdieu's study of the stem family of Béarn. ${ }^{47}$ Although the primacy of males over females and of the eldest over the younger siblings appeared here less strongly, the categorical imperative to keep the house and the patrimony intact was very much the same, resulting in the formation of what Lamaison called "patrimonial lineages". But Lamaison also suggested, in a very Lévi-Straussian vein, that the functioning of the whole system depended on a flow of exchanges of spouses and property (in the form of dowries), which linked together the various lineages. The most intriguing finding was that there were "exchange cycles", whereby dowries flowed through several lineages but ultimately went back to the original lineages. A simplified diagrammatic representation of one of these cycles is given in Figure I, which shows that exchange could extend over several generations and resemble what Lévi-Strauss had called, in his analysis of elementary structures, "generalized exchange". As Lamaison himself acknowledged, this exchange cycle (which started in 1680 and closed down only in I 823) was an extreme case. But the mechanism involved, he claimed, was the same as those found in shorter cycles. Since it appeared that the direction and frequency of these exchanges were not random, it seemed advisable to speak of strategies "whose aim - perhaps not altogether a conscious one - [was] to establish networks of relations and solidarities, but also to permit the pursuit of an effective and continuing practice of reciprocity through the transfer of dowries"..$^{8}$

Lamaison's concept of "exchange cycle" may be confused with the concept of bouclage, or "closure of descent chains", that Héritier proposed,49 but they are in fact quite different. The concept of "closure of descent chains" rests on Héritier's prediction that in "traditional" societies with complex systems (not, therefore, twentieth-century urban societies) marriages preferentially take place with relatives whose genealogical position lies immediately beyond the core of prohibited degrees. As Héritier's crosscultural evidence suggested that prohibition tended everywhere to extend up to the fourth degree (which is also the case of Church regulations in the West), the frequency of marriages of the type represented in Figure 2 (or permutations of it) could be expected to be

47. Pierre Lamaison, "Les stratégies matrimoniales dans un système complexe de parenté: Ribennes en Gévaudan (I650-1830)", Annales ESC, 34 (1979), pp. 72 I-743. See also Elisabeth Claverie and Pierre Lamaison, L'impossible mariage: Violence et parenté en Gévaudan (Paris, I982), pp. 270-297.

48. Lamaison, "Stratégies matrimoniales", p. 738.

49. Françoise Héritier, L’exercice de la parenté (Paris, 1981). 


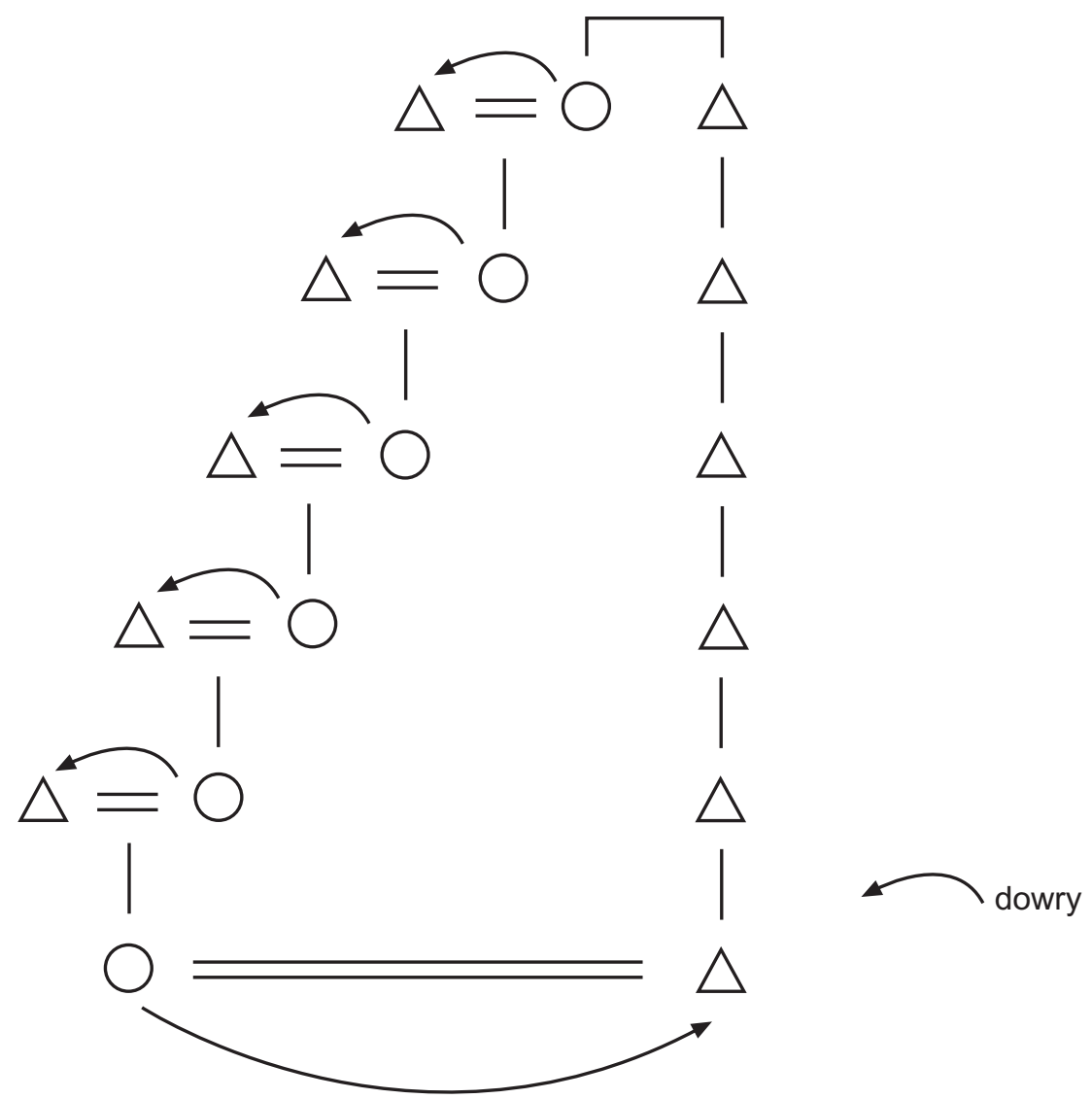

Figure r. "Exchange cycle" (adapted from Pierre Lamaison, "Les stratégies matrimoniales dans un système complexe de parenté', p. 735)

much higher than would be the case if all marriages were made at random..$^{\circ}$

Although evidence for western Europe is rather conflicting, ${ }^{\text {sI }}$ if we assume that Héritier is right, then there must be an explanation for this

50. To identify "preferential" marriage patterns, Lévi-Strauss suggested the criterion of a frequency significantly higher than would be the case if all marriages were made at random (“Future of Kinship Studies", p. 18).

5I. Martine Segalen pointed out that neither Lamaison's study of the Gévaudan nor her own data on Brittany bore out Héritier's contention; "Du nouveau à propos de la parenté dans les sociétés paysannes”, Ethnologie Française (n.s.), I4 (1984), pp. 79-85. Héritier's theses appear, on the other hand, to be supported by Raul Merzario in Il paese stretto. Strategie matrimoniali nella diocesi di Como, secoli XVI-XVIII (Turin, I98I); and Gérard Delille, Famille et propriété dans le Royaume de Naples, XVe-XIXe siècle (Paris [etc.], I985). 


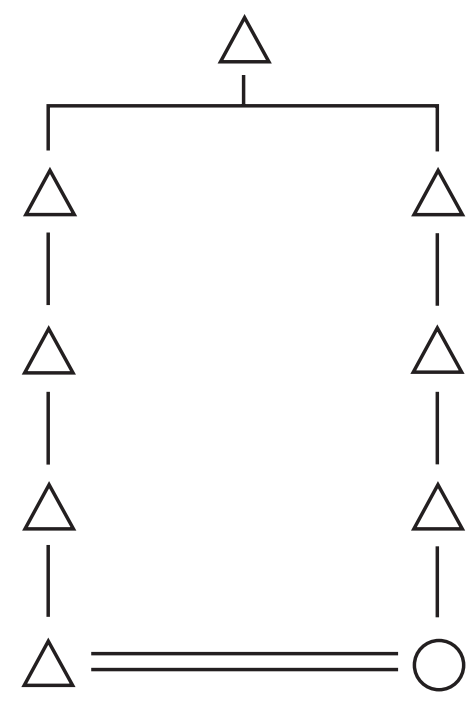

Figure 2. "Closure of descent chains" (adapted from Françoise Héritier, L'exercice de la parenté, p. I53).

“preferential” pattern. As with Lamaison's "cycles", it would seem logical to account for it as the product of strategies. But is this permissible? It is a basic point in exchange theories that some time must elapse before one reciprocates, and it has been convincingly argued that waiting is a crucial component of human strategic behavior. ${ }^{22}$ However, to interpret a marriage (and the related transfer of dowry) as the outcome of a longterm strategy consciously started between Ioo and i 50 years earlier, one clearly has to stretch this notion beyond the limits of plausibility. And, in fact, neither Lamaison nor Héritier claimed as such. Rather, these authors saw these as strategies pursued not by individuals or by families, but rather by the system as a whole - as structural arrangements essential to the functioning of the system. ${ }^{53}$

Echoing what Lévi-Strauss once said of the structuralist study of myth, we might say that the aim of these anthropologists was not so much to show how (and why) people pursued strategies as to show how strategies operate without people being aware of the fact. ${ }^{54}$ As Héritier herself

52. Elster, Ulysses and the Sirens, pp. 9-10. See also Bourdieu, Outline, p. 6.

53. See Héritier, L'exercice de la parenté, pp. 160-166, and especially Lamaison, "Stratégies matrimoniales", p. 722. "Tout semble mis en oeuvre pour que, grâce aux alliances, l'ensemble du système puisse se perpétuer: chaque union apparait comme le fragment d'une stratégie globale visant à ce maintien.”

54. Claude Lévi-Strauss, Le cru et le cuit (Paris, I964), p. 20: "Nous ne prétendons pas montrer comment les hommes pensent dans les mythes, mais comment les mythes se pensent dans les hommes, et à leur insu." 
acknowledged, this raises the question of whether "one should place a sociological value on structures which are discovered by sophisticated methods of analysis but which would not be immediately recognized as their own strategies by the population which practice them". 55 While Héritier dismissed this question as ultimately unimportant, other eminent anthropologists did not agree with her. In a rather critical discussion of Héritier's book, Emmanuel Terray denounced the danger of treating society "as a perceptive and intelligent individual, capable of deciding his objectives and developing the means to achieve them"; and Segalen, also in a critical vein, argued that it would be more fruitful and legitimate to focus on what she called "horizontal" alliances, which "work in a conscious way since they involve fewer generations". ${ }^{6}$ In her book on family life in Brittany, Segalen stressed that alliances of the kind Héritier predicted were far from constituting a "preferential" marriage form, and maintained that the hypothesis to be tested was "that of a conscious behavior, a preference for marriage with known kin". 57

Yet, Héritier's theory had considerable impact on the work of family historians in France and elsewhere. Indeed, some studies appear to support her contentions, including Raul Merzario's analysis of nuptiality in some hilly and mountainous parts of the northern Italian diocese of Como, and Delille's major work on family and property in the Kingdom of Naples. ${ }^{58}$ Both books are especially relevant not only because they explicitly aimed at testing Héritier's hypotheses, but also because they revealed in a clearer way the ambiguity of the position that proponents of this approach hold.

On the one hand, Merzario regarded the regularities he brought to light in his investigation as evidence of "collective strategies", which he saw as the sum of the strategies that individual families pursued. For Merzario, the study of these collective strategies (of which the actors were obviously unaware) required the "sophisticated methods of analysis" that Héritier mentioned. For him, the crucial problem was "to identify a mathematical relation which w[ould] enable [him] to decipher the logic of marriage exchange". 59 On the other hand, Merzario's work largely dealt with marriages that seemed to be the outcome of conscious, if short-term, tactics. He stressed, in particular, the high frequency of marriages between close relatives apparently imposed by their poverty and requiring dispensation from Church authorities. ${ }^{60}$ But even marriages between

55. Héritier, L'exercice de la parenté, p. I6 I.

56. Emmanuel Terray, “Sur l'exercice de la parenté", Annales ESC, 4I (I986), pp. 259-270, 269; and Segalen, "Du nouveau", p. 8r.

57. Martine Segalen, Quinze générations de Bas-Bretons: Parenté et société dans le pays bigouden sud $1720-1980$ (Paris, 1985), pp. 38I-382.

58. Merzario, Il paese stretto, and Delille, Famille et propriété.

59. Merzario, Il paese stretto, p.I45.

6o. Ibid., pp. I53-154. 
cousins in the fourth degree (which in certain periods were so numerous that it seems justified to regard them as a form of preferential marriage) appeared to obey rather immediate concerns. Merzario's qualitative evidence indicated that the people involved in these marriages saw them as a good way of reinforcing links of friendship, neighborliness, and economic cooperation between families who shared a common ancestor, but who were on the verge of failing to recognize each other as related through kinship.

This suggests that short-term strategies - what we prefer to call tactics and not long-term strategies may have determined the closure of long-term "exchange cycles". We cannot consider them as long-term strategies, since the final marriages ensuring the closure of descent chains were certainly not planned by ancestors of newly married couples. In view of the many social, economic, demographic, and spatial constraints that affected the marriage market in the various village communities, it is not surprising that marriages tended to display some regularities. It would be useful if methods could be devised to formalize these regularities elegantly and economically. However, to use the term "strategy" to describe these regularities and their social and economic effects such as the circulation of property or increases in solidarity, confuses the issue and introduces an unfortunate teleological element.

\section{BOURDIEU'S MODEL REVISITED}

Although a number of historians and anthropologists have departed from Bourdieu's kind of analysis, it is indisputable that his notion of family strategy has enjoyed enormous diffusion among students of European peasantries. ${ }^{61}$ As the author of one of the best studies in the Bourdieuesque mould observed, many welcomed the notion of strategy because it furnished "a means of linking and mediating between the two levels of individual 'choice' and societal 'structure' without placing excessive emphasis upon either one". ${ }^{62}$ Besides reacting to Bourdieu's theoretical stimuli, however, both anthropologists and anthropologically-minded historians have also tended to adopt the whole "package" of assumptions about the nature of the peasant family which Bourdieu had derived from his ethnographic study of the Béarn region of the Pyrenees. Since there may be a danger in applying a concept of strategy originally developed for

6r. In addition to the Lévi-Straussian line represented by works such as those of Lamaison, Héritier, Merzario, and Delille, strategic approaches more influenced by Barth's model than by Bourdieu's have also been widely adopted. For anthropology, see Ladislav Holy, Strategies and Norms in a Changing Matrilineal Society: Descent, Succession and Inheritance among the Toka of Zambia (Cambridge, 1986), pp. 198-2 10; for history, Giovanni Levi, Inheriting Power: The Story of an Exorcist (Chicago, IL, I988).

62. Brian Juan O’Neill, Social Inequality in a Portuguese Hamlet (Cambridge, 1987), p. 196. 
property-owning peasants living in an upland area of Europe in the early twentieth century to other places and other times, it is useful to examine, however briefly, some problems with Bourdieu's model which have not received the attention they deserve.

One important, but often neglected, issue is the degree of compatibility between the various strategies which a family can be expected to pursue to achieve a given goal. A good example is the stress Bourdieu placed on the salience of the ideal of "keeping the family name on the farm" - an ideal which tallies well with the picture of European peasant society as characterized by a strong association between a family and an ancestral house with its attendant property. The first requisite was to keep the name on the farm and see to it that family land was not sold to outsiders or even divided among family members. The second requisite was that the "biological continuity of the lineage", to use Bourdieu's own phrase, ${ }^{63}$ should be assured. But are these two requisites easily compatible?

According to Bourdieu, the reasons why family land should not be subdivided were partly a matter of affective attachment and partly a matter of prestige, for a division of land could lower the social standing of the family. But it is worth noting that particularly those students of European peasantries who have worked on upland societies (including Bourdieu himself) also appear to regard impartibility as a sort of optimal solution to the basic environmental problem peasants must face in marginal areas, namely the need to avoid land fragmentation in order to preserve economically viable estates. ${ }^{64}$ From this point of view, impartibility would be what ecological anthropologists call a sound "adaptive strategy". ${ }^{65}$ There seem, therefore, to be both ideological and ecological reasons to favor impartibility. In a system in which marriage depends on one's ability to inherit, however, impartibility often results in widespread

63. Bourdieu, "Stratégies matrimoniales", p. i 106.

64. See, for example, ibid., p. I I 2; John W. Cole and Eric R. Wolf, The Hidden Frontier: Ecology and Ethnicity in an Alpine Valley (New York, 1974), pp. 174-275; Agnès Fine-Souriac, "La famille-souche pyrénéenne au XIXe siècle", Annales ESC, 32 (I977), pp. 478-487, 483; Lamaison, "Stratégies matrimoniales", p. 722; and Brian Juan O’Neill, "Dying and Inheriting in Rural Trás-os-Montes", Journal of the Anthropological Society of Oxford, I 4 (1983), pp. 44-74, 73. For a general discussion, see Pier Paolo Viazzo, Upland Communities (Cambridge, I989), pp. $93-96$ and $258-268$.

65. Robert E. Rhoades and Stephen I. Thompson, "Adaptive Strategies in Alpine Environments: Beyond Ecological Particularism", American Ethnologist, 2 (1975), pp. 535-55I. Whether impartibility represents a better "adaptive strategy" in mountain areas than partibility is actually debatable, since the adaptive advantages of impartibility become evident only if we assume - as most anthropologists implicitly or perhaps inadvertently have done - that population is increasing and consolidation mechanisms are not available. Among the first anthropologists to recognize these points were Ellen Wiegandt, "Inheritance and Demography in the Swiss Alps", Ethnobistory, 24 (1977), pp. I33-I48, esp. pp. I39-I40, and Theodore E. Downing, "Partible Inheritance and Land Fragmentation in Oaxaca Valley", Human Organization, 36 (1978), pp. $235-243$. 
celibacy - a condition which Bourdieu himself described for the Béarn in another well-known article. ${ }^{66}$ This, in turn, entails a high risk of lineage extinction, especially when marriage is not only infrequent but also late, as was the case in the Béarn. ${ }^{67}$ As a result, strategies shaped by the goal of keeping the farm undivided simultaneously tend to jeopardize the biological continuity of the lineage.

Indeed, one major limitation of Bourdieu's model was that it assumed that peasant family strategies were essentially aimed at stemming the danger arising from a surplus of potential heirs, which was seen as obvious and posing a threat to the integrity of the family farm. A demographically more sophisticated framework would have brought to the fore the problem raised by the scarcity of heirs, showing that in every conceivable population, some families were bound to have too few heirs and others too many, and that proportions changed with changing demographic circumstances. In fact, one might argue that it is precisely the high risk of family or lineage extinction that makes a strategic approach most fruitful analytically, for it directs attention to what Jack Goody termed "strategies of heirship", i.e. the ways that families - or heads of families - use legal or institutional devices to cope with a scarcity of heirs. ${ }^{68}$ The modeling procedures that Goody and others pioneered to estimate the probability of parents having no heir among their offspring and the rate of patriline extinction, are an indispensable complement to Bourdieu's strategic approach, since only by placing observed behavior within a solid demographic framework can we decide whether behavior resulted from choices between alternatives or was dictated by demographic constraints. ${ }^{69}$

Another weakness displayed by anthropological students of European peasant societies who adhere to Bourdieu's view of family strategy has been their tendency to consider "peasant strategies" in isolation from a number of crucial constraints, as if peasant families had a completely free hand on their land and were simply playing a mini-max game with the environment. Yet, even a quick survey of works on the functioning of inheritance patterns in historic Europe makes one wonder whether the

66. Pierre Bourdieu, "Célibat et condition paysanne", Etudes Rurales, 5-6 (1962), pp. 32-I35.

67. Bourdieu, "Stratégies matrimoniales", p. I 22.

68. Jack Goody and Graham A. Harrison, "Strategies of Heirship", Comparative Studies in Society and History, is (1973), pp. 3-20, reprinted as Chapter 7 of Jack Goody, Production and Reproduction (Cambridge, I976).

69. See Edward Anthony Wrigley, "Fertility Strategy for the Individual and the Group", in Charles Tilly (ed.), Historical Studies of Changing Fertility (Princeton, NJ, I978), pp. I35-I 54, whose argument is developed by Richard M. Smith, "Some Issues Concerning Families and Their Property in Rural England, I250-I800", in Richard M. Smith (ed.), Land, Family and Life-Cycle (Cambridge, I984), pp. I-86. On patriline extinction, see Kenneth W. Wachter and Peter Laslett, "Measuring Patriline Extinction for Modeling Social Mobility in the Past", in Kenneth W. Wachter, Eugene A. Hammel, and P. Laslett, Statistical Studies of Historical Social Structure (New York, 1978), pp. I13-135. 
integrity of the farm was the aim of the peasantry, as is usually assumed, or rather the aim of dominant power-holders. To be sure, a few studies particularly of the Austrian peasantry - have shown that in some circumstances the aims of both parties could partially converge, and that feudal lords could find willing allies among the members of the peasants' families. ${ }^{70}$ More frequently, however, the "strategies from above" that landlords pursued powerfully constrained peasant families' "strategies from below" - a point that studies of serf families in Russia and other parts of eastern Europe have made clear. ${ }^{7 \mathrm{I}}$

We have already remarked that Bourdieu's model envisages mainly "defensive" strategies whose purpose was to pass on the farm as intact as possible to the next generation, to keep the heir's siblings celibate, or to find a way of "repairing" a lineage on the verge of extinction. To do so, the head of the peasant household had simply to circumvent legal rules and cope with demographic and environmental constraints. Little attention is paid to the fact that he had also to interact with other human actors - be they the landowners, as in the examples just cited, or perhaps other household heads who, as Davis remarked, also wanted to increase their patrimony or create one if it did not already exist. These latter strategies we may call "aggressive", and they obviously make the whole picture more complex, and the analytical task of historians and anthropologists more difficult. It may be that some kinds of social structures encourage one type of strategy more than the other. However, both "defensive" and "aggressive" strategies may easily coexist in the same system, and in most cases, the gains of one family are bound to involve, directly or indirectly, losses for others. Moreover, defensive strategies designed to assure the integrity of a patrimony may have been the springboard for more acquisitive behavior later on, when the general economic or demographic circumstances, or perhaps more favorable phases in the family's own development, made it possible to buy some more land or to take over a larger farm..$^{2}$

It is relevant to notice, in this respect, that the family strategies that Bourdieu analyzed were predicated on the absence of a land market. $\mathrm{He}$ portrayed a social system where the dominant ideal, to which all strategies were ultimately subservient, was that a family should own the same house

70. An impressive study is Hermann Rebel, Peasant Classes: The Bureaucratization of Property and Family Relations under Early Habsburg Absolutism, ISII-I636 (Princeton, NJ, I983).

7г. See Czap, "A Large Family", and especially Rodney D. Bohac, "Peasant Inheritance Strategies in Russia”, Journal of Interdisciplinary History, I6 (1985), pp. 23-42.

72. Daniel Bertaux and Isabelle Bertaux-Wiame made a somewhat similar methodological point in "Le patrimoine et sa lignée: transmissions et mobilité sociale sur cinque générations", Life Stories/Récits de Vie, 4 (1988), pp. 8-26. They remark that family strategies should not be seen as just ways of coping with constraints but also as responses to availability of desirable resources and other kinds of "positive" opportunities, possibly created by previous generations in the family and conditioning the behavior of subsequent generations. 
and the same land over generations. The household head was seen not as the owner of family land but rather as its temporary manager in the interest of the lineage. His task was to assure that the patrimony passed on intact. As Alan Macfarlane commented, "a busy land market not only destroys such ideals, but is logically incompatible with them". ${ }^{73}$ A busy land market, however, is hardly incompatible with what we have called "aggressive" strategies. His own study of kinship, inheritance, and the sale of property in Neckarhausen, and a critical survey of the literature on the real-estate market in historic Europe, have led David Sabean to conclude that the market was not an independent mechanism for dissolving family relations, as suggested by some historians (including Macfarlane), "but c[ould] be an instrument of family strategies in competition with each other" ${ }^{74}$

This is an important shift both in the focus of inquiry and in the theoretical orientation of the analysts. However, it is not without problems. The easiest way of reconstructing strategies in a land market context is to concentrate on the so-called "successful" families, which are a minority, but are likely to have survived for longer periods and to have left more traces of themselves in notarial archives because of their greater activity in the land market. This approach may offer useful insights but fatally tends to produce a twisted or highly incomplete picture. As Richard Smith indicated in his introduction to Land, Kinship and Life-Cycle, in order to understand correctly the functioning of a land market and isolate the genuinely strategic element in it, it is essential that we develop flexible models encompassing many different variables and constraints: the institutional framework, the various sources of income available to a family, the effects of the "demographic lottery", and the consequences of long-term economic and demographic changes..$^{75}$

A promising step forward - and one of special relevance in view of the issues discussed in this paper - was Ian Blanchard's contribution to Land, Kinship and Life-Cycle, where he examined the structure of the land market in a number of Derbyshire townships between I 380 and I $520 .{ }^{76} \mathrm{He}$ focused mainly on relationships between two groups (or, perhaps, categories) of families apparently pursuing different but often complementary land-market strategies: on the one hand, those who obtained their livelihood solely from agriculture, which were said to be pursuing

73. Alan Macfarlane, The Origins of English Individualism (Oxford, I978), p. 24.

74. Sabean, Property, Production, and Family, p. 4I 2. Other studies suggesting the land market as a profitable setting to observe family strategies at work include David Siddle, "Inheritance Strategies and Lineage Development in Peasant Society", Continuity and Change, I (1986), pp. 333-36r; Levi, Inheriting Power; and several papers in Smith, Land, Kinship and Life-Cycle.

75. Smith, "Some Issues Concerning Families".

76. Ian Blanchard, "Industrial Employment and the Rural Land Market I380-1520", in Smith, Land, Kinship and Life-Cycle, pp. 227-275. 
"defensive" strategies aimed at the preservation of the integrity of the family holding; and on the other, families who combined industrial and agricultural activities, which followed "aggressive" strategies in which they used cash they earned by their industrial work to make what Blanchard called "predatory forays" into the rural land market. Though so different in character, the two groups and the tactics they deployed were linked by a sort of symbiotic relation. The "industrial" families had to operate in a market where supply was determined by the availability of land temporarily alienated by the "agricultural" families, which at certain stages of their developmental cycle had to shed excess land in order to eliminate short-term disequilibria between land and labor. The "agricultural" families, for their part, had to rely on the demand for land originating in the "industrial" families. According to Blanchard, however, the "agricultural" families retained "reversionary rights" whereby they could resume the ownership of land they had alienated when it was superfluous to their needs. This, he believed, explained why, in spite of the passage of land through as many as three or four nonfamily hands, there was a marked tendency for these plots ultimately to revert into the possession of the original family or patriline.

Blanchard's study had the great merit of assembling and organizing many important variables in an unusually elegant and imaginative way. In addition, it was anthropologically attractive because it provided the key to making sense of some of the most intriguing aspects of Lamaison's model of exchange cycles. However, as in the case of Lamaison's model, the question of intentionality remained open. Before we can confidently accept Blanchard's contention that land tended to return to families that had strategically discarded it for a while, it is necessary to demonstrate more rigorously that this happened not merely through chance, but on purpose..$^{77}$

This leads to an issue of considerable significance to both historians and anthropologists, namely the question of establishing, so to speak, "how strategic strategies can be". On the anthropological side, it is worth noticing that in one of the texts that opened up the way to the strategic approach in anthropology, Raymond Firth, while stressing the need to concentrate more heavily on the analysis of planned action, also emphasized that a variety of constraints may impose limitations on the range of alternatives possible and that "the arc within which seemingly free choice is exercisable is often very small". ${ }^{7}$ In another highly influential paper, the economic historian Claudia Goldin made largely the same point. In past times, she remarked, the ability of ordinary people to plan and make strategic decisions was severely limited by economic, social, and 
institutional constraints; "but families, at some point in time, began to control more of their present and of their future lives and eventually were capable of planning long-run strategies of life". ${ }^{79}$

At what point in Western history meaningful long-run strategies became feasible and conceivable is a matter of debate, and it may well be that more than one answer is possible depending on the kind of strategy involved. Goldin seemed to imply that the household labor allocation strategies became the norm some time in the nineteenth century. Strategies involving patrimonial accumulation, on the other hand, might have become fairly common at a rather earlier stage, as Davis and others argued. It remains doubtful, however, that historians of the European working class can usefully employ the notion of strategy when referring to fertility patterns, as Tilly did as part of her exploration of working-class families, when she argued that parents in different industrial settings not only organized their household and children's labor contributions by sending or withholding them from various labor markets, but that they also developed a "high fertility strategy". ${ }^{80}$

\section{DETECTING CONSCIOUS STRATEGIES IN THE PAST}

From what we know of fertility in the past, the notion of a high fertility strategy seems ill-placed, at least if we accept that all strategies involve some level of intentionality. The available evidence suggests that until the late nineteenth century in most areas of Europe (the late eighteenth century for France) the vast majority of working-class couples did not subject their fertility behavior to strategic control. ${ }^{81}$ Birth spacing behavior, while acknowledged in some settings and suggesting the presence of a conscious fertility strategy, is notoriously difficult to document. It is true that workers' fertility remained high long after members of the European upper middle and middle classes had begun to limit theirs. However, the persistence of high fertility and the fact that it occurred among couples who could send their children out to work are insufficient - in the absence of more direct evidence - to support the notion of a fertility strategy. Certainly, from what we know of the difficulties of implementing contraceptive practices at the end of the nineteenth century, we might accept the idea that working-class men

79. Claudia Goldin, "Family Strategies and the Family Economy in a Late Nineteenth-Century American City", in Theodore Hershberg (ed.), Philadelphia: Work, Space, Family, and Group Experience in the Nineteenth Century (New York, I981), pp. 277-310, 279.

80. Tilly, "Individual Lives", p. I44.

8I. For a contrary view, see the discussion in Simon Szreter, Fertility, Class and Gender in Britain, I860-I940 (Cambridge, I996), pp. 488-50I, and Dov Friedlander, Barbara S. Okun, and Sharon Segal, "The Demographic Transition Then and Now: Processes, Perspectives, and Analyses", Journal of Family History, 24 (1999), pp. 493-533, 508-510. 
thought high fertility a desirable strategic goal. Yet given women's expressed desire to limit the number of their pregnancies, it seems difficult to accept, without direct evidence, that working-class women were willing participants in a high-fertility strategy whose rationality lay in the availability of waged work for their children. ${ }^{82}$ Much like Lamaison or Delille, Tilly seems to infer strategies from patterned evidence alone.

Since studies of the onset of conscious fertility regulation within marriage both in western Europe and the United States suggest that changed economic forces helped precipitate the intrusion of documentable, conscious strategizing about marital fertility, a question remains. ${ }^{83}$ If there was a time in the past when married couples did not think and act strategically regarding their fertility, where did intentional strategies come from? Here, another of Bourdieu's concepts seems quite helpful, involving as it does his belief that most human behavior - even rational behavior does not result from conscious strategies, but from habitus - which he understands as a conglomeration of familiar responses and customary behavior. How can we get from habitus to conscious behavior strategy, such as the one that seems to have informed the transition from uncontrolled to controlled fertility during the demographic transition?

It is possible that innovative strategies that actually existed in the minds of historical actors can come from reshaping the adaptive rationality that very often lies within customary or habitual behavior, but that nonetheless falls short of truly strategic behavior. An interesting example can be found in Simon Szreter's study of the British fertility decline, in his investigation into what he calls a "culture of abstinence" - the fact that sexual abstinence within marriage was a familiar behavior to couples who conformed to religious proscriptions on sexual intercourse during sacred times of the church calendar, particularly Lent. ${ }^{84}$ Building upon Szreter's discussion, it seems reasonable to hypothesize that this repertoire of behavior imbedded in religious culture, in the presence of other factors, could later serve to facilitate the adoption of abstinence within marriage in the interests of strategic, parity-dependent fertility control. Familiar cultural practices brought together in Bourdieu's notion of habitus - may therefore provide

82. Wally Seccombe, "Starting to Stop: Working-Class Fertility Decline in Britain", Past and Present, I 26 (1990), pp. I I I-I 88.

83. Louis Henry, Anciennes familles genevoises: Etude Démographique, XVIe-XXe siècle (Paris, 1956); Nancy Osterud and John Fulton, "Family Limitation and Age at Marrriage: Fertility Decline in Sturbridge, Massachusetts, I730-I850", Population Studies, 30 (1976), pp. 48-94; Louise Kantrow, "Philadephia Gentry: Fertility and Family Limitation among an American Aristocracy", Population Studies, 34 (1980), pp. 21-30; and Daniel Scott Smith, “Early' Fertility Decline in America: A Problem in Family History", Journal of Family History, I 2 (1987), pp. 73-84.

84. Szreter, Fertility, Class and Gender, pp. 389-424. 
the raw materials for the invention and elaboration of individually-based and fully conscious strategies. ${ }^{85}$

Tilly's attribution of conscious choice to workers' experience of high fertility drew less criticism than her perpetuation of the notion of families as "unitary" decision-making units. Critics of family strategy note that the concept obscures potential internal differentiation of interests within the household, and implies consensus where none may exist. Indeed, certain scholars argue that it is just "a shorthand for describing the product of the different interests of the household members and their differential ability to have their own wishes followed by their co residents" ${ }^{86}$ Feminist critics of family strategy have been most eager to identify intrahousehold conflicts between the genders. ${ }^{87}$ Others resorted to a variety of "conflict" models, where the adoption of one strategy or another is explained as an outcome of bargaining among family members with differing interests and unequal resources. ${ }^{88}$ Yet, to be fair, it is important to note that one of the foremost anthropological critics of the "consensus" model of family strategy, Sylvia Yanagisako, has also expressed serious reservations about the alternative "conflict" model on the basis of the results of her research on co-residential strategies among Japanese Americans. She argues that "the conflict model of household struggle runs the risk of too readily assuming that what drives human action is universal self-interest and a pan-cultural will to power rather than culturally constructed goals and motives" ${ }^{89}$ It would thus be ill-advised to assume that the members of a household inevitably have conflicting wishes or goals. The question of the "indoctrination" of subordinate family members that Bourdieu raised is surely an important one. And as Tilly herself suggested, a focus on those

85. Bourdieu suggests the existence of a number of "fertility strategies" among his Béarnais peasants. Among these were a high age at marriage, especially in the late nineteenth century. "Stratégies matrimoniales," I I 22, fn. 35.

86. David I. Kertzer and Andrea Schiaffino, "Industrialization and Co-residence: A Life-Course Approach', in P.B. Baltes and O.G. Brim (eds), Life-span Development and Human Behavior (New York, 1983), pp. 360-391, 366.

87. Diane L. Wolf, "Does Father Know Best? A Feminist Critique of Household Strategy Research", Research in Rural Sociology and Development, 5 (1991), pp. 29-43.

88. Tilly, "Beyond Family Strategies", p. I 25. Of special relevance has been, in this respect, the emphasis which feminist scholars have placed on gender. See Nancy Folbre, "Family Strategy, Feminist Strategy", Historical Methods, 20 (1987), pp. I I - I I 8; and Barbara Laslett and Johanna Brenner, "Gender and Social Reproduction: Historical Perspectives", Annual Review of Sociology, Is (1989), pp. 38 I-404, esp. 382-386.

89. Sylvia Junko Yanagisako, "Explicating Residence: A Cultural Analysis of Changing Households among Japanese-Americans", in Robert M. Netting, Richard R. Wilk, and Eric J. Arnould (eds), Households: Comparative and Historical Studies of the Domestic Groups (Berkeley, CA, 1984), pp. 330-352, 343. For a rejoinder to certain elements of the feminist critique of consensus models of family bargaining behavior in the past, see Tessie P. Liu, "Le Patrimoine Magique: Reassessing the Power of Women in Peasant Households in NineteenthCentury France", Gender and History, 6 (1994), pp. I3-36. 
courses of action in which individual interests appear to be subordinated to collective interests might provide a sharper perception of who exactly bears the costs or benefits from them..$^{\circ}$

\section{CONCLUSION}

Given the difficulties of inferring strategies from patterned data, would it be better simply to admit that "family strategies" is really only a template that historians and anthropologists have overlaid on behavior that has a patterned quality? Clearly not, since certain investigations have gathered credible direct evidence that strategies have existed in the minds and behaviors of people under investigation. However, it is also clear that studying large numbers (or sometimes even small numbers) of events such as those familiar to historians of the family or historical demographers inevitably yield patterns of some kind. Determining whether these patterns resulted from human volition is another matter. We suggest that patterned behavior, such as the age-ordered marriage of siblings that Daniel Scott Smith discovered in colonial New England (and that began to break down in the late eighteenth century) may have been an example of Bourdieu's "matrimonial strategies", especially if we accept his belief that strategies do not need to be conscious. ${ }^{9 \mathrm{I}}$ On the other hand, we suggest that such patterns may well have resulted simply from conformity to custom or habitus as Bourdieu defined it.

The thrust of our remarks is that Bourdieu's notion of strategy or its transmutation into the idea of family strategy is unhelpful because it admits the presence of unconscious strategies; it can lead to confusion about the objects and subjects of strategies; and, especially in the absence of Bourdieu's notion of habitus, has led social historians and anthropologists to impute strategies to groups of persons when the only evidence consists of aggregate patterns of behavior. We have tried to show that while the widespread use of the notion of strategy initially helped to boost the sense of human agency, thus mitigating the sense of people's powerlessness in structuralist models, its use has often exaggerated the choices that people in the past faced.

To mitigate some of these problems, we argue for a more skeptical turn of mind that infers strategies only on the basis of direct evidence or

90. Tilly, "Individual Lives", p. I38.

91. Daniel Scott Smith, "Parental Power and Marriage Patterns: An Analysis of Historical Trends in Hingham, Massachusetts", Journal of Marriage and the Family, 35 (1973), pp. 4064I 8, 425. In her "Women's Marital Timing at the Turn of the Century: Generational and Ethnic Differences", The Sociological Quarterly, 38 (1997), pp. 567-585, 580, Sharon L. Sassler concludes, with no direct evidence, that delayed marriage among second-generation Jewish women in the United States was part of an "ethnic family strategy" (our emphasis). 
extremely strong indirect evidence from the context being studied. We suggest the use of vocabulary that more carefully distinguishes those who make and those who are affected by strategies. In many instances, we believe that the use of the more modest term "tactics" better captures the short-term time horizon and lack of control over external circumstances that people have and that the term strategies tends to conceal. ${ }^{92} \mathrm{We}$ also believe that Bourdieu's idea that strategies can be unconscious, while appealing in some respects, is largely unusable. Bourdieu's notion of habitus seems fully adequate for describing a set of beliefs and practices that inform and guide people's behavior below the level of consciousness.

The study of how families actually function would be very much enriched by the greater development of scholarship on how different members "constructed" the family in their own minds and behavior. This would take us further towards pursuing the "emic" task so important to many social and cultural anthropologists. As the work of such historians as Christiane Klapisch-Zuber demonstrated for written records in the Italian Renaissance, the way that different historical actors constructed "the family" in whose interests they claimed to act deserves more critical inquiry, using the sorts of qualitative texts that bear the expression of such thoughts. ${ }^{93}$

Having spent a good deal of space criticizing some of the problems with Bourdieu's legacy to historians and anthropologists, we close by acknowledging that Bourdieu devoted some attention to this idea, and in so doing pointed the way towards undoing the tendency to reify the family as a collective actor - one of the unfortunate by-products of the use of "family strategies". In Practical Reason, Bourdieu cited approvingly the work of ethno-methodologists who emphasize that "family", far from being simply in the nature of things, is "socially constructed". In "family discourse", he wrote, "the language that the family uses about the family, the domestic unit is conceived as an active agent, endowed with a will, capable of thought, feeling and action". However, the work of constructing the "family" involves individuals who have a multiplicity of interests and agendas. The ways they construct their own visions of the family have important consequences in the worlds of daily life. Thus, for Bourdieu,

92. Katherine A. Lynch, "Infant Mortality, Child Neglect, and Child Abandonment in European History: A Comparative Analysis", in Tommy Bengtsson and Osamu Saito (eds), Population and Economy: From Hunger to Modern Economic Growth (Oxford, 2000), pp. I3364 , fn. I 8 .

93. See, most notably, Christiane Klapisch-Zuber, "Kin, Friends, and Neighbors: The Urban Territory of a Merchant Family in 1400", in Women, Family, and Ritual in Renaissance Italy (Chicago, IL [etc.], 1985), pp. 68-93, for a discussion of how one Florentine constructed his family and kin group for narrative purposes. 
"the family" is a convenient or a "well-founded fiction". ${ }^{94}$ The family points to an important "field" of action; it is "collectively recognized"; and points to a real and ongoing set of relationships. Gaining greater insight into the ways that individuals - sorted by age, gender, class, or even individual sensibility - have "constructed" this family differently through their views of the world and their actions may well allow us to reconstruct the goals of the groups they compose more accurately.

94. Pierre Bourdieu, Practical Reason: On the Theory of Action (Stanford, CA, I 998), pp. 65-66. For a more radical statement of the social construction of kinship and gender relations, see Jane Fishburne Collier and Sylvia Junko Yanagisako, "Toward a Unified Analysis of Gender and Kinship", in idem (eds), Gender and Kinship: Essays toward a Unified Analysis (Stanford, CA, I987), pp. I4-50. 